\title{
EVOLUTION OF THE RIVER REGA VALLEY NEAR LOBEZ IN LATE PLEISTOCENE AND EARLY HOLOCENE
}

\author{
BERNARD CEDRO \\ Department of Geology and Palaeogeography, Institute of Marine Sciences, \\ Faculty of Natural Sciences, University of Szczecin \\ Felczaka 3a, 71-412 Szczecin
}

Received 24 May 2007

Accepted 20 August 2007

\begin{abstract}
The River Rega valley near Łobez was formed by a rapid icesheet degradation. Evolution of valleys of rivers (including the Rega) discharging into the Baltic Sea began in late Plenivistulian; it was then that glacifluvial outwash levels and kame terraces were formed. At that time, the water was flowing southward and further on towards the south-west, in a broad channel. That period was terminated at the turn of Plenivistulian and late Vistulian, when the discharge became directed northwards. The net result was the onset of the formation of the modern Rega valley system, buried chunks of dead ice still in the process of melting. Dead ice melt-down proceeded at the fastest rate during Allerød. It was then that deposits of organic matter were formed, the deposits being most probably remnants of fossil soil. Plant macro-fossils and remains of freshwater malacofauna point to a sporadic occurrence of sediments of a shallow water body which existed on the melt-down site of a huge chunk of dead ice. The thickness of the overlaying mineral cover (up to $6 \mathrm{~m}$ ) is indicative of a fast sediment accretion rate. Sandy and silty sediments were deposited in synchrony with the dead ice melting. As a result, today's Rega valley features traces of small melt-water lakes as well as fossil sedimentation basins (underlain by the Allerød organic level), rapidly filled with fluvial and fluviolimnic sediments. Since the Preboreal, the Rega has been flowing along a meandering channel.
\end{abstract}

Keywords: Rega valley, dead ice, sedimentology, lithostratigraphy, Late Pleistocene, Early Holocene

\section{INTRODUCTION}

Development of river network and formation of river valley in the young-glacial area of Poland has already been discussed in the literature for a long time. The major focus was most frequently directed to large ice-marginal valley and valley forms, primarily in the Noteć-Warta ice-marginal valley, coastal ice-marginal valley (particularly that of Reda-Łeba), as well as the lower Vistula and lower Odra valleys (Kozarski, 1962; Galon, 1968 and 1972; Brykczyński, 1986). Geological and geomorphological research in smaller valley forms began with a certain delay with respect to studies on large river valleys (Sylwestrzak, 1978; Florek, 1991; Błaszkiewicz, 1998 and 2005). It is at present accepted that the development of valley relief in coastal areas was controlled primarily by:

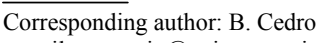

e-mail: petromin@univ.szczecin.pl

ISSN 1897-1695 (online), 1733-8387 (print) C 2007 GADAM Centre, Institute of Physics, Silesian University of Technology.

All rights reserved.
- drainage of meltwater, resulting in the formation of lake troughs and outwash valleys;

- melting of dead ice chunks;

- flow of melting and extraglacial waters leading to the formation of ice-marginal valley;

- flow of precipitation-fed extraglacial waters leading to the formation of fluvial valleys.

The complex process of dead ice melting and its effects on river valley morphology has been commented upon by a few authors only: Kozarski (1963), Florek (1991), Böse (1995), Błaszkiewicz (1998 and 2005), Starkel (2001), Vandenberghe (2003).

\section{AREA AND AIM OF STUDY}

The study was carried out in the River Rega valley dissecting the Łobez Plateau (Fig. 1). With its length of $199 \mathrm{~km}$, the Rega is one of the major Pomeranian rivers. It originates in the Drawsko Lakeland (Połczyn Zdrój municipality) in the hinterland of the major frontal mo- 


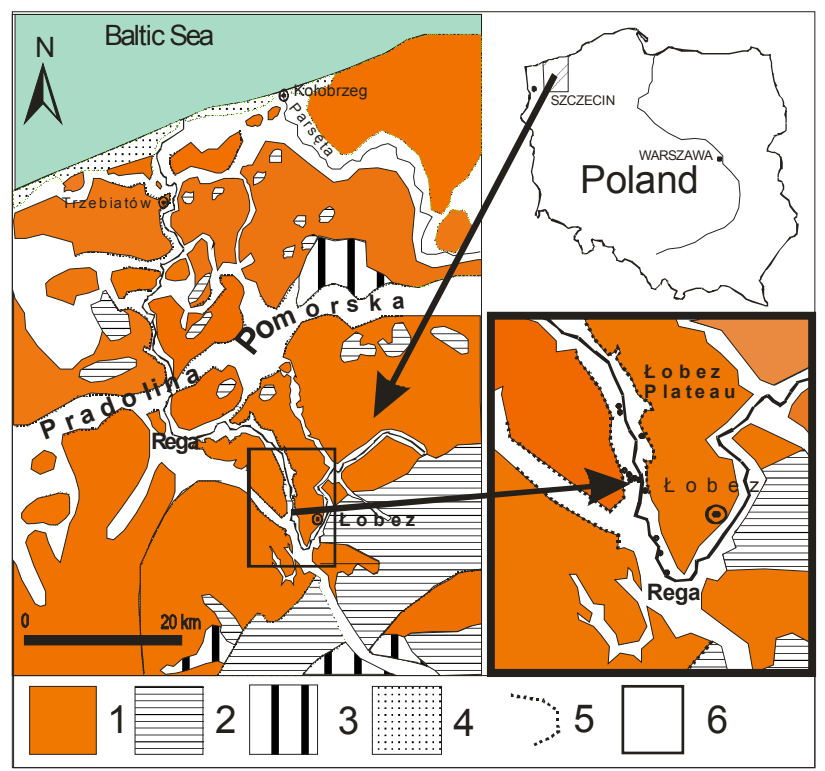

Fig. 1. Geomorphogical sketch after Augustowski (1977), modified. 1 - morainic plateau, 2 - accumulation morainic hills, 3 - outwash plains, 4 - dune fields, 5 - high edges of uphills and valleys, 6 - research area.

raines, in the vicinity of the village of Imienko near Bierzwnica, at the altitude of $177.5 \mathrm{~m}$ a. s. 1. The Rega belongs directly to the Baltic Sea catchment. It collects water from the area of $2724.9 \mathrm{~km}^{2}$ and discharges to the Baltic near Mrzeżyno. Along the stretch discussed in this paper, the Rega valley is a fragment of two joined subglacial troughs incising the morainic plateau to 45-50 m (Fig. 2). The present day's bottom of the valley lies at the altitude changing from $51 \mathrm{~m}$ a. s. 1 . in the southern part to $47 \mathrm{~m}$ asl in the north. The river gradient in the area is $0.8 \%$. The flood plain in the Rega valley fragment analysed varies in width from 50 to $300 \mathrm{~m}$.

The Rega valley geology is very poorly known. Similarly to other major rivers of the northern slope of Pomerania, the Rega originates in the morainic zone of the socalled lakeland hump - a watershed formed as a result of several Pleistocene glaciations. The area was shaped by degradation of the icesheet cap within a very short period of time (Kozarski, 1995). The complex deglaciation processes gave rise to a mosaic of morainic and glacifluvial surfaces incised by a network of marginal and erosional valleys.

This study was aimed at revealing the major stages of the Rega valley development during the icesheet deglaciation both at the end of the Plenivistulian and during the late Glacial and Holocene. The objectives of the study could be met by analysing the morphology of the valley itself and its immediate surroundings. Lithostratigraphic analyses as well as characterisation of the sediment cover on the valley's bottom and on individual terrace levels, too, made it possible to cast light on phases in the valley's development. Reconstruction of changes that were taking place in the area were also be possible by determining the thickness, distribution, and lithologic characteristics of the Rega valley sediments, and by exploring the rate and conditions of sedimentation in the valley's bottom.

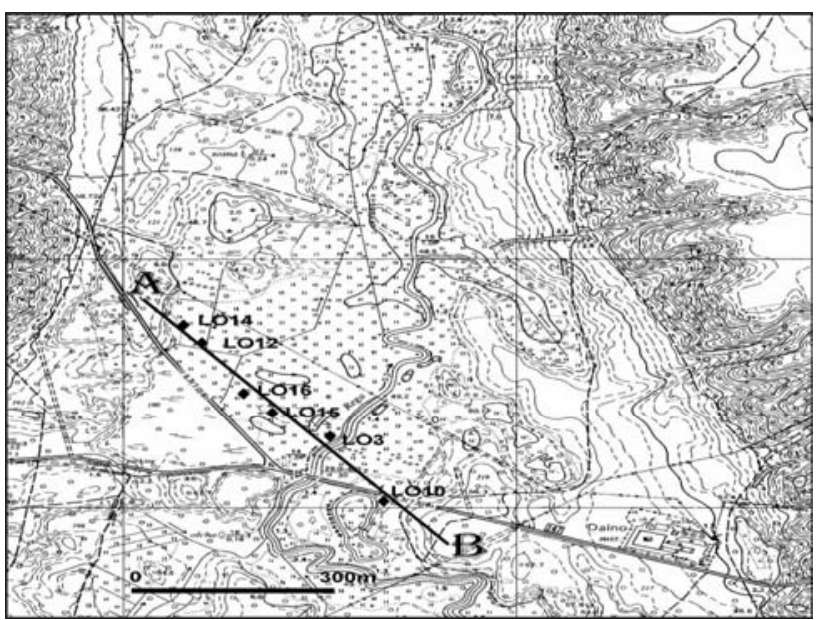

Fig. 2. A fragment of hipsographic map with location of boreholes; $A-B$ - line of the cross-section presented in the Fig. 4.

Of the major coastal rivers, it is only the Rega that, so far, has not been studied comprehensively enough with respect to the development of its valley during the late Glacial and Holocene. The author has already made initial attempts aimed at providing the missing information (Cedro, 2003, 2004a, 2004b, 2005 and 2006).

\section{METHODS OF STUDY}

A hypsometric map (Fig. 2) of the Rega valley fragment analysed was used to lay out a number of transverse and longitudinal transects in the terraces. The terrace levels were identified by analysing a 1:10,000 topographic map and by comparing transverse profiles through the Rega valley taken, on the average, every $0.5-1 \mathrm{~km}$.

The geological set-up of the Rega valley fragment selected for this study (Fig. 1) was studied in 2002-2005, based on a number of drillings that made it possible to collect precisely located samples for laboratory analyses. Using a MERES drill (Rotnicki et al., 1999), a total of 16 boreholes were made down to the depth of 5.5-12.5 m. Six boreholes were located in the trough section of the valley, north of the bridge on the Rega, by the LobezNowogard road. Grain size composition of sandy and sandy-gravelly sediments was determined by sieving sediment samples collected from selected transects. Sieving analysis was performed on a Retsch sieve set and a Retsch AS 200 control g sieve shaker. Grain size composition of sandy-silty and silty-clayey sediments was analysed using a Malvern Mastersizer laser particle analyzer $(0.3-300 \mu \mathrm{m}$ range). Selected samples of organic sediments were radiocarbon dated in the C14 Laboratory, Institute of Physics, Silesian University of Technology.

\section{RESULTS}

The area of study was found to feature 8 terrace levels (Fig. 3; Cedro, 2006): the lowest-lying flood terrace (terrace $\mathrm{I}$, a flood plain) extends to $1.5 \mathrm{~m}$ above the Rega water level; terrace II (supra-flood terrace) is situated at the height of $2.5-3 \mathrm{~m}$; terrace III is found at the height of 


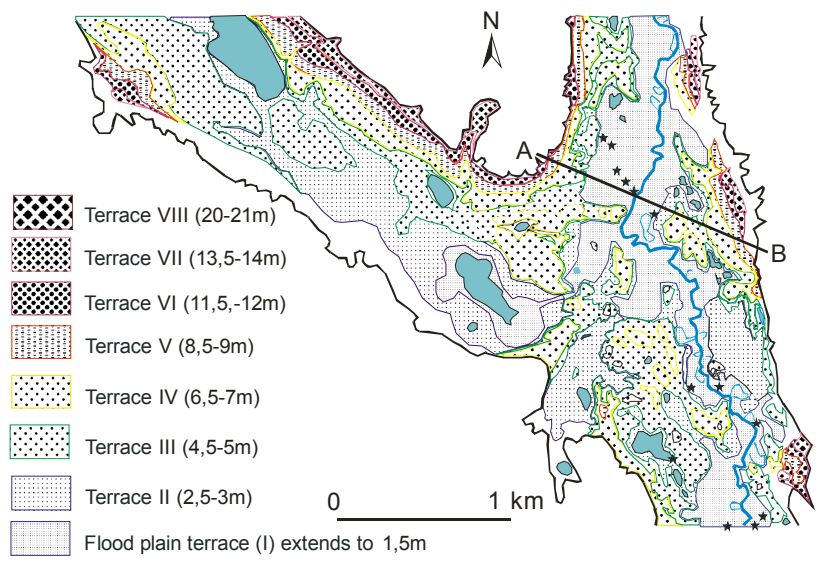

Fig. 3. Terrace levels range in the Rega valley, near Łobez.

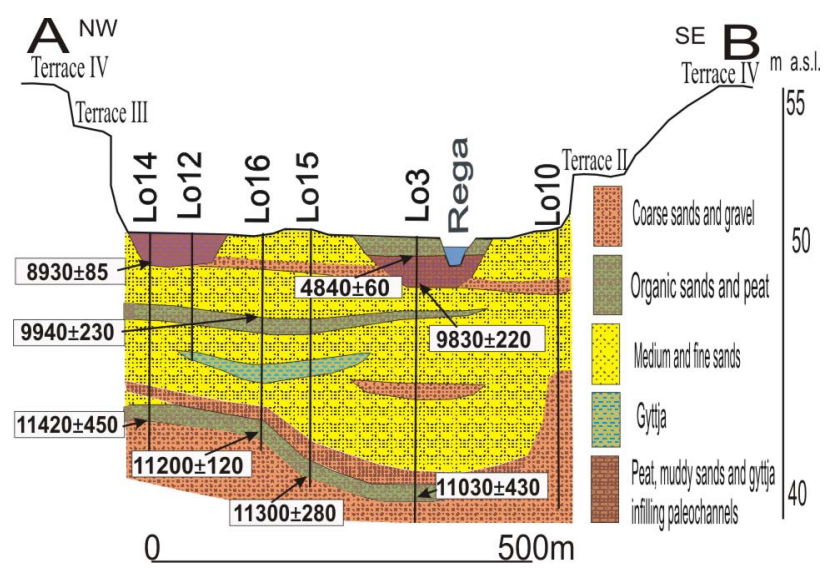

Fig. 4. Geological cross section, located N of bridge over the Rega, by the Łobez-Nowogard road.

4.5-5 m; terrace IV is situated at $6.5-7 \mathrm{~m}$; terrace $\mathrm{V}$ occurs at $8.5-9 \mathrm{~m}$; terrace VI is at $11.5-12 \mathrm{~m}$, and terrace VII lies at $13.5-14 \mathrm{~m}$. The last terrace level (VIII) is discernible at $20-21 \mathrm{~m}$ above the valley bottom and is virtually invisible in the valley fragment studied.

It was possible to conclude, with a high probability, that the oldest sediments of known age, bored from the profiles Lo3, Lo14, Lo15, and Lo16 (Table 1, Fig. 4) were deposited in Allerød. In profile Lo16, the sediments were bored at the depth of $6 \mathrm{~m}$ where a thin peat cover overlies sands and silts containing plant macroremnants and freshwater malacofauna represented by the gastropods Gyraulis albus, Armiger crista f. cristatus, Valvata pulchella, Valvata piscinalis, and Limnaea sp. and by the bivalve Pisidium sp.

They are underlain by medium and coarse sands of about $1 \Phi$ mean grain size (Fig. 5). Those sands found above the lower organic level show varying grain size. The mean grain size of those sediments varies from 0.7 to 2.8Ф. They show negative skewness (mean skewness of about -0.2$)$ and high kurtosis (1.0-1.4). The top part of the profile (Lo3/7 and Lo3/10) shows biogenic sediments, deposited in Early Holocene (Preboreal) and Subboreal in the lower and upper part, respectively. Apart from those sediments, there are also fine-sand and silt formations. A similar sequence (except for the lack of sandy and silty
Table 1. Dating and calibration results.

\begin{tabular}{|c|c|c|c|c|}
\hline \multirow{2}{*}{ Sample name } & \multirow{2}{*}{ Lab. No. } & \multirow{2}{*}{${ }^{14} \mathrm{C}$ age (BP) } & \multicolumn{2}{|c|}{$\begin{array}{l}68.2 \% \text { confidence inter- } \\
\text { vals }\end{array}$} \\
\hline & & & $\begin{array}{l}\text { Cal. age range } \\
\text { (BP) }\end{array}$ & $\begin{array}{l}\text { Prob. } \\
(\%)\end{array}$ \\
\hline Lo-14/9 & Gd-12884 & $8960 \pm 85$ & $\begin{array}{l}10230-10110 \\
10070-9920\end{array}$ & $\begin{array}{l}31.5 \\
36.7\end{array}$ \\
\hline Lo-14/32 & Gd-17321 & $11420 \pm 450$ & $13800-12850$ & 68.2 \\
\hline Lo-3/7 & Gd-12804 & $4840 \pm 60$ & $\begin{array}{l}5560-5570 \\
5540-5480\end{array}$ & $\begin{array}{l}39.4 \\
28.8\end{array}$ \\
\hline Lo-3/10 & Gd-16399 & $9830 \pm 220$ & $11750-10750$ & 68.2 \\
\hline Lo-3/45 & Gd-18324 & $11030 \pm 430$ & $13450-12350$ & 68.2 \\
\hline Lo-15/100/ORG & Gd-30121 & $11300 \pm 280$ & $13410-12920$ & 68.2 \\
\hline Lo-16/32 & Gd-30119 & $9940 \pm 230$ & $12000-11150$ & 68.2 \\
\hline Lo-16/49 & Gd-12890 & $11200 \pm 120$ & $13200-12980$ & 68.2 \\
\hline
\end{tabular}

sediments in the uppermost part) was recorded in the profile Lo14. The bottom, biogenic layer of these sediments was deposited in Allerød and the peats of the top layer in early-Holocene. The layers are separated by finegrained sands and silts $3.5 \mathrm{~m}$ thick. The uppermost sections of both profiles represent sediments infilling the palaeomeanders.

\section{DISCUSSION AND CONCLUSIONS}

Evolution of coastal river beds (including that of the Rega) began at the end of the Plenivistulian, when glacifluvial levels (outwash and valley outwash) emerged. Deglaciation was rapid and the lack of vegetation cover enhanced the mobility and large supply of bedload (Florek, 1991). At that time, the meltwater in the presentday Rega valley flowed southwards and towards the south-west (Galon, 1968). That period terminated at the turn of Plenivistulian and late Vistulian, when a northward discharge flow was formed. Morphological analysis of terrace levels in the Rega Valley allows to conclude that older terraces (V-VIII) may be kame in character. They occur most often as isolated, irregular levels and flats on trough slopes. Areas featuring kame form accumulation were limited to small areas between slopes of trough depressions and the ice that filled the valley or to small depressions in the ice. The direction of flow related to the formation of the levels has not been studied so far. On the other hands, terraces II, III, and IV were most probably developing under conditions of branching flow, as evidenced by the presence of numerous isolated, elongated and flat-topped hills and depressions on the valley's bottom, which may be interpreted as between-channel flats and branching channels, respectively. Most of them show a north-south trending, which is particularly distinct in the southern part of the studied area (Fig. 3). At the same time, terrace IV is the most distinct and the best visible one in all the valley sections analysed (also in those located beyond the Łobez environs discussed here). Terrace IV, which occurs along the entire section north of Trzebiatów, is related to a period when, most probably, the river began functioning as a homogenous fluvial system (Cedro, 2006). Dead ice melting was at its most intensive in the Allerød. That was the time when the organic matter, discovered in profiles Lo3, Lo14, Lo15, and 

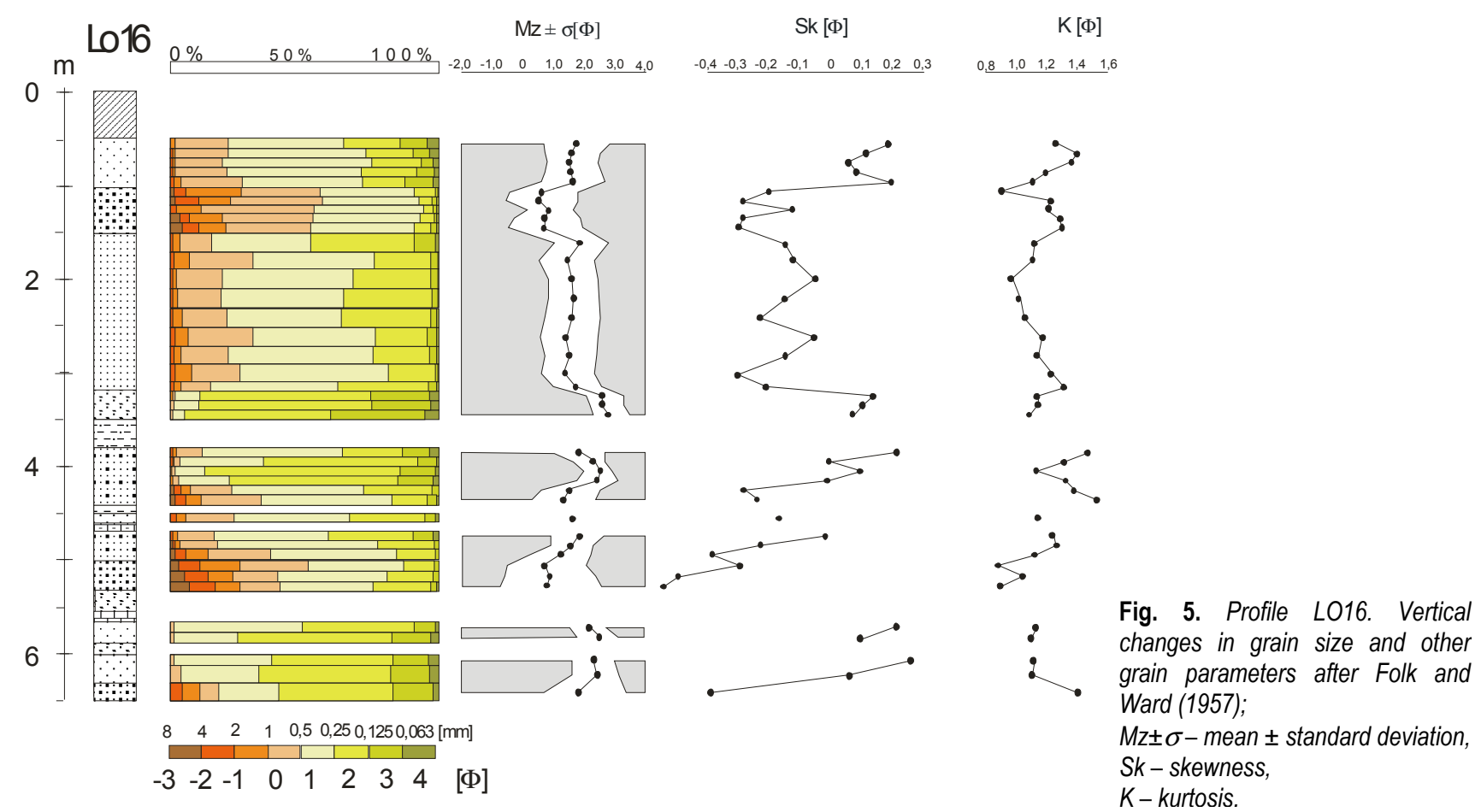

Lo16, was deposited, visible as - most probably - fragments of a fossil soil. Sporadically found are also sediments of a shallow water body that emerged at the site where a large chunk of dead ice melted, as evidenced by plant macroremnants and freshwater malacofauna. The thickness of the overlying mineral layer (up to $6 \mathrm{~m}$ ) bears evidence of a fast sediment accretion during about 1000 years. The sandy and silty sediments discussed were deposited synchronously to melting of the dead ice chunk. A large number of sites in the young-glacial area of the Central European Lowland shows the dead ice melting in depressions to span a long period of time, from the oldest Dryas to the late Preboreal (Błaszkiewicz, 2005). The most frequently invoked causes of the temporal differences include differences in the thickness of the mineral layer covering the dead ice. In addition to the mineral layer thickness, also the size and morphology of the dead ice must have been important. In his latest paper, Błaszkiewicz (2005) provided a detailed documentation of the process and paid a particular attention to the evolution of lacustrine depressions in river valleys. The vicinity of streams and the consequent possibility of permanent drainage and bottom erosion may be assumed to act as factors slowing down the melting processes. Thus, there is every reason to conclude that the process of melting did take place in the area discussed, and that the final meltdown of the dead ice occurred as late as at the beginning of the Preboreal.

The variability of grain size observed along the profile and involving the presence of numerous gravel beds and silt-clay layers among the sandy sediments is indicative of the branching type of drainage. Since the Preboreal, a meandering drainage system was developing, as evidenced by the sediments in palaeomeanders found in profiles Lo3, Lo14, and Lo12. The peat deposits occurring there were dated at the early Holocene. In the Preboreal, the river migration zone was very wide. The zone determines the present horizontal dimensions of the flood terrace. Similar conclusions were drawn by Florek (1991) for Central Pomeranian rivers. This is understandable if one considers the fact that the annual mean river flow rate in the early Holocene was much faster than that at present, as indicated by palaeohydrological research carried out not only in Pomerania (Florek, 1991), but also in the Polish Lowland (Rotnicki, 1991; Kozarski and Rotnicki, 1978; Rotnicki and Młynarczyk, 1989). The relatively high flow rate, at full-channel states, produced shore erosion and a fast river bed migration, as indicated by relatively small age differences obtained from palaeomeander peats collected in the vicinity of profiling sites Lo3, Lo12, and Lo14, the sites being located about $400 \mathrm{~m}$ apart. The high susceptibility of the river bed shores to erosion resulted from a loose vegetation cover, prevalent at the time. The advent of the Sub-boreal is marked by a small aggradation of the bottom of the valley in a narrow belt adjacent to the present Rega channel. The early Holocene peats are overlain by very fine sands and silt with a high organic matter content, deposited in Subboreal as indicated by radiocarbon dating. This provides evidence of a higher supply of mineral material to the river bed. It was most probably associated with progressing deforestation of the drainage area by the Neolithic peoples.

As shown by the data, development of the valley landscape in the area was at its most intensive from the Allerød until the early Holocene during the meltdown of dead ice chunks. The last 10,000 years witnessed relatively little changes produced mainly by the meandering river. Numerous fossil fragments and oxbows observed at present were formed at that time as well.

The study was supported by the Polish Committee for Scientific Research grant No. 2PO4E 04129. 


\section{REFERENCES}

Augustowski B, 1977. Pomorze (Pomerania). Warszawa, PWN: 350pp (in Polish).

Błaszkiewicz M, 1998. Dolina Wierzycy, jej rozwój w późnym plejstocenie i wczesnym holocenie (Wierzyca valley, evolution in Late Pleistocene and Early Holocene). Dokumentacja Geograficzna 10: 1-116 (in Polish)

Błaszkiewicz M, 2005. Późnoglacjalna i wczesnoholoceńska ewolucja obniżeń jeziornych na Pojezierzu Kociewskim - wschodnia część Pomorza (Late glacial and early Holocene evolution of the lake basins in the Kociewskie Lakeland -Eastern part of the Pomerania Lakeland). Prace Geograficzne 201: 1-192 (in Polish).

Böse M, 1995. Problem of dead ice and ground ice In the central part of the North European Plan. Quaternary International 28: 123-125, DOI 10.1016/1040-6182(95)00039-L.

Brykczyński M, 1986. O głównych kierunkach rozwoju sieci rzecznej Niżu Polskiego w czwartorzędzie (Principal directions in development of river system in Polish Lowland in Quaternary). Artykuł dyskusyjny. Przeglad Geograficzny 58(3): 411-440 (in Polish).

Cedro B, 2003. Postglacjalne i holoceńskie osady fluwialne, jeziornobagienne i morskie w dolinie Regi koło Mrzeżyna (Postglacial and Holocene sediments: fluvial, swampy and maritime in Rega valley near Mrzeżyno). In: Borówka RK and Witkowski A, eds., Człowiek $i$ środowisko przyrodnicze Pomorza Zachodniego. Szczecin, Oficyna IN PLUS: 47-49 (in Polish).

Cedro B, 2004a. Rekonstrukcja sedymentacji postglacjalnych i holoceńskich osadów fluwialnych, morskich i jeziorno-bagiennych doliny Regi w rejonie Mrzeżyna (Reconstruction of sedimentation of Postglacial and Holocene deposits: fluvial, swampy and maritime in Rega valley in region of Mrzeżyno). Dokumentacja Geograficzna 31: 29-31 (in Polish)

Cedro B, 2004b. Rekonstrukcja zmian środowiskowych zapisanych w vistuliańskich i holoceńskich osadach doliny Regi w okolicy Mrzeżyna (Environmental changes reconstruction recorded in Vistulian and Holocene sediments of Rega valley in Mrzeżyno vinicity). In: Błaszkiewicz M and Giereszewski P, eds., Rekonstrukcja $i$ prognoza zmian środowiska przyrodniczego $w$ badaniach geograficznych. Prace Geograficzne 200: 59-67 (in Polish)

Cedro B, 2005. Wstępne uwagi o wieku osadów wypełniających dolinę Regi w rejonie Łobza i jej ujściowym odcinku w rejonie Mrzeżyna (Preliminary notes about age of sediments in Rega valley in vicinity of Łobez and in estuary sector in Mrzeżyno region). In: Borówka RK, ed., Plejstoceńskie $i$ holoceńskie przemiany środowiska przyrodniczego Polski. Wybrane aspekty. Szczecin, Oficyna InPlus: 13-16 (in Polish).

Cedro B, 2006. Poziomy terasowe w dolinie Regi koło Łobza. (Terrace levels in the Rega Valley near Łobez). In: Koźmiński C, Dutkowski M and Radziejewska T, eds., Człowiek $i$ Środowisko Przyrodnicze Pomorza Zachodniego III. Szczecin, Print Group: 76-83 (in Polish).

Florek W, 1991. Postglacjalny rozwój dolin rzek środkowej części północnego skłonu Pomorza (Postglacial development of river valleys in the middle part of the northern slope of Pomerania). WSP Słupsk: 238pp (in Polish).

Folk RL and Ward WC, 1957. Brazos River Bar: a study in the significance of grain size parameters. Journal of Sedimentary Petrology 27: 3-27.
Galon R, 1968. Ewolucja sieci rzecznej na przedpolu zanikającego ladolodu (Evolution of river system in vicinity of decay continental glacier). In: Galon R, ed., Ostatnie zlodowacenie skandynawskie w Polsce. Prace Geograficzne IG PAN 74: 101-120 (in Polish).

Galon R, 1972. Główne etapy tworzenia się rzeźby Niżu Polskiego (The main stage of creation of Polish Lowland relief). In: Galon R, ed., Geomorfologia Polski 2. Warszawa, PWN: 35-110 (in Polish).

Kozarski S, 1962. Recesja ostatniego ladolodu z północnej cześci Wysoczyzny Gnieźnieńskiej a kształtowanie się Pradoliny NoteciWarty (Recession of the last continental glacier from north part of Gniezno morainic plateau and forming Notec-Warta ice-marginal valley). Prace Komisji Geograficzno-Geologicznej, Poznańskie Towarzystwo Przyjaciół Nauk 2(3): 153pp (in Polish).

Kozarski S, 1963. O późnoglacjalnym zaniku martwego lodu w Wielkopolsce Zachodniej (Late Glacial decay of dead ice in Western Wielkopolska). Badania Fizjograficzne nad Polska Zachodnia A 24: 51-60 (in Polish).

Kozarski S, 1995. Deglacjacja północno-zachodniej Polski: Warunki środowiska i transformacja geosystemu ( $20 \mathrm{ka} \rightarrow 10 \mathrm{ka}$ BP) Deglaciation of northwestern Poland: environmental conditions and geosystem transformation ( $20 \mathrm{ka} \rightarrow 10 \mathrm{ka} \mathrm{BP})$. Dokumentacja Geograficzna 1: 82pp (in Polish).

Kozarski S and Rotnicki K, 1978. Problemy poźnowürmskiego i holoceńskiego rozwoju den dolinnych na Niżu Polskim (Late Würm and Holocene problems of the valley botoms development on Polish Lowland area). Prace Komisji Geograficzno-Geologicznej Poznańskie, Towarzystwo Przyjaciół Nauk 19: 57pp (in Polish).

Rotnicki K, 1991. Retrodiction of paleodischarges of meandring and sinus alluvial rivers and paleoclimatic implications. In: Starkel L, Gregory $\mathrm{KJ}$ and Thornes $\mathrm{JB}$, eds., Temperate paleohydrology, Chichester, Wiley: 431-470.

Rotnicki K and Młynarczyk Z, 1989. Późnowistuliańskie i holoceńskie formy i osady korytowe w dolinie środkowej Prosny i ich paleohydrologiczna interpretacja (Late Vistulian and Holocen channel forms and deposits of the middle Prosna river and their paleohydrological interpretation). Poznań, Wydawnictwo Naukowe UAM, Geografia 43: 76pp (in Polish).

Rotnicki K, Młynarczyk Z and Szczot S, 1999. „MERES” - małogabarytowe urządzenie do płytkich wierceń geologicznych. („MERES” - small-gabarit equipment for not deep geological borings) In: Borówka RK, Młynarczyk Z and Wojciechowski A eds., Ewolucja geosystemów nadmorskich poludniowego Battyku, PoznańSzczecin, Bogucki Wydawnictwo Naukowe: 161-168 (in Polish).

Starkel L, 2001. Historia doliny Wisły od ostatniego zlodowacenia do dziś (Evolution of the Vistula river valley Since the last glaciation till present). Warszawa, IGiPZ PAN, Monografie 2: 263pp (in Polish).

Sylwestrzak J, 1978. Zagadnienia morfologii i typizacji dolin północnego skłonu Pomorza (Chosen problems of the morphology and classification of the types of valleys on the northern slope of Pomerania). Biuletyn Instytutu Geologicznego 306. Z badań czwartorzędu w Polsce 21: 199-231 (in Polish).

Vandenberghe J, 2003. Climate forcing of fluvial system development: an evolution of ideas. Quaternary Science Reviews 22: 2053-2060, DOI 10.1016/S0277-3791(03)00213-0. 